\title{
UPAYA MENINGKATKAN PEMAHAMAN SISWA KELAS VII B MELALUI METODE \\ PEMBELAJARAN OBSERVASI PADA MATERI KLASIFIKASI HEWAN \\ DI SMP NEGERI 2 KASIHAN BANTUL TAHUN AJARAN 2011/2012
}

\author{
Gangsar Tri Handini, Muhammad Joko Susilo
}

\begin{abstract}
ABSTRAK
$\mathbf{P}$ enggunaan metode yang baik dan tepat dapat berpengaruh dalam proses dan pencapaian tujuan pembelajaran. Seperti yang terjadi dalam proses pembelajaran di kelas VII B SMP Negeri 2 Kasihan Bantul bahwa aktivitas belajar siswa masih rendah dan belum mencerminkan pembelajaran yang terpusat pada siswa selain itu hasil belajar siswa belum sesuai dengan standar KKM sekolah. Karena itu diperlukan solusi untuk meningkatkan aktivitas dan pemahaman siswa. Salah satu upaya untuk meningkatkan aktivitas dan pemahaman siswa adalah dengan menggunakan metode observasi. Tujuannya untuk mengetahui apakah metode observasi dapat memperbaiki kualitas proses pembelajaran siswa pada materi klasifikasi hewan, dan mengetahui berapa siklus yang dilakukan untuk meningkatkan kualitas proses pembelajaran pada materi klasifikasi hewan di SMP Negeri 2 Kasihan Bantul.

Penelitian ini merupakan penelitian tindakan kelas yang dilakukan di SMP Negeri 2 Kasihan Bantul sebanyak 2 siklus dengan subyek penelitian adalah siswa kelas VII B sebanyak 38 siswa. Instrumen yang digunakan adalah lembar observasi dan soal objektif, dengan perolehan data melalui observasi aktivitas siswa. Post-tes sebagai data tingkat pemahaman siswa.

Penggunaan metode pembelajaran observasi dapat meningkatkan kualitas proses pembelajaran, dan meningkatkan pemahaman siswa dengan perbaikan pembelajaran disiklus II. Berdasarkan dilihat dari hasil peningkatan aktivitas belajar siswa yaitu 32,89 \% menjadi 44,74 \%, dan hasil nilai rata-rata pemahaman siswa dari posttes siklus I dan Siklus II yaitu 66,18 menjadi 75,39.
\end{abstract}

Kata kunci: Pemahaman siswa, Metode Pembelajaran Observasi, Klasifikasi Hewan, Aktivitas belajar 


\section{PENDAHULUAN}

Berdasarkan observasi yang dilakukan bersamaan dengan pelaksanaan PPL II di SMP Negeri 2 Kasihan Bantul menunjukkan bahwa proses pembelajaran cenderung text book oriented dan tidak terkait dengan kehidupan sehari-hari. aktivitas siswa rendah dan rata-rata hasil belajar siswa masih di bawah KKM yaitu 56 sedangkan KKM yang di gunakan yaitu 70, proses belajar mengajar pada materi klasifikasi hewan masih monoton, guru masih menggunakan metode ceramah, peranan siswa dalam kegiatan pembelajaran masih kurang aktif.

Partisipasi siswa selama proses pembelajaran cenderung hanya mencatat dan mendengarkan penjelasan guru, siswa sulit sekali untuk mengajukan pertanyaan dan pendapat bahkan cenderung diam. Akibatnya interaksi guru dan siswa hanya berlangsung satu arah sehingga suasana pembelajaran menjadi membosankan. Kondisi demikian menjadi faktor yang menyebabkan siswa mengalami kejenuhan dalam belajar sehingga aktivitas belajar siswa dalam memahami materi tersebut masih rendah dan berdampak pada rendahnya pemahaman siswa terhadap materi pembelajaran.

Oleh karena itu, perlu dikembangkan metode atau strategi pembelajaran biologi yang dapat melibatkan siswa secara aktif dalam proses pembelajaran untuk menemu- kan dan menerapkan ide-ide siswa karena keaktifan siswa dalam mengikuti proses belajar mengajar merupakan salah satu kunci keberhasilan pencapaian tujuan pembelajaran.

Pada materi klasifikasi hewan siswa dituntut untuk memahami keanekaragaman makhluk hidup dan mengklasifikasikan makhuk hidup berdasarkan ciri - ciri yang dimiliki, sehingga untuk memahami materi tersebut perlu dilakukan kegiatan belajar mengenal objek pembelajaran secara langsung yang dibimbing oleh guru agar siswa mampu bekerjasama dan terlibat aktif dengan sesama dalam menyelesaikan suatu permasalahan materi pembelajaran.

Untuk itu diperlukan suatu upaya yang dapat meningkatkan pemahaman siswa. Penelitian ini dilakukan di kelas VII B karena memiliki karakteristik pemahaman siswa rendah yang di tunjukan dengan hasil belajar pada materi klasifikasi hewan masih rendah. Upaya untuk meningkatkan pemahaman siswa adalah melalui penerapan metode yang tepat dan sesuai dengan materi pembelajaran. Alasannya adalah : (1) dengan metode pembelajaran yang tepat dapat membantu siswa dalam memahami materi, (2) metode pembelajaran dipandang sebagai salah satu unsur penting dalam rangka mencapai tujuan pengajaran. Penggunaan metode yang tepat akan membuat proses pembelajaran menjadi lebih efektif karena dengan metode yang 
tepat siswa akan mampu memahami materi pelajaran dengan lebih mudah.

Metode pembelajaran merupakan alat untuk mencapai tujuan pengajaran yang ingin dicapai sehingga penggunaan metode yang baik dan tepat akan semakin berhasil sebagai sarana pencapaian tujuan. Salah satu upaya untuk meningkatkan pemahaman siswa adalah dengan menggunakan metode observasi. Harapannya dengan menerapkan metode pembelajaran observasi dapat memberi solusi dari masalah tersebut.

Kelebihan dari metode observasi adalah siswa dilibatkan untuk turut berpikir sehingga emosi siswa dapat terlibat langsung dalam proses pembelajaran, meningkatkan keterampilan siswa melalui suatu kegiatan, dapat mengamati suatu proses/kejadian dengan sendirinya, sehingga akan memperkaya pengalaman dan meningkatkan serta membangkitkan rasa ingin tahu. Siswa akan lebih memahami sesuatu yang bersifat konkrit dan lebih mampu mengingat dalam jangka waktu yang relatif lebih lama.

Berdasarkan uraian di atas penulis mencoba melakukan penelitian dengan mengangkat judul penelitian, Upaya Meningkatkan Pemahaman Siswa Kelas VII B Melalui Metode Pembelajaran Observasi pada Materi Klasifikasi Hewan di SMP Negeri 2 Kasihan Bantul.

\section{METODE PENELITIAN}

\section{A. Jenis Penelitian}

Penelitian ini adalah penelitian tindakan, dimana siswa dalam proses belajar mengajar disuguhkan materi pelajaran dan cara pengajaran yang menarik sehingga nantinya akan memotivasi siswa dalam belajar dan akhirnya dapat meningkatkan hasil belajar mereka dalam materi klasifikasi hewan.

\section{B. Setting Lokasi Dan Subjek Peneli- tian}

Penelitian ini dilakukan di SMP Negeri 2 Kasihan Bantul yang beralamat di jalan Bibis, Jetis, Tamantirto, Kasihan, Bantul, khususnya pada siswa kelas VII B tahun ajaran 2011/2012 dan dilaksanakan pada bulan juni 2012. Penentuan waktu penelitian mengacu pada kalender akademik sekolah.

\section{Rancangan Penelitian \\ 1. Menyusun perencanaan}

Melakukan observasi awal untuk identifikasi masalah dan analisis penyebab masalah melalui wawancara dengan guru bidang studi Biologi. Dalam penelitian ini ditetapkan pula tindakan solusi pemecahan masalah melalui metode observasi. Dengan cara mengikuti sekenario pembelajaran sebagai berikut : Menyusun instrumen penelitian berupa silabus, rencana pembelajaran (RP) dan mempersiapkan alat dan bahan yang diperlukan dalam proses pembelajaran, 
membuat lembar observasi aktivitas siswa, kuisioner tanggapan siswa dan guru dalam mengikuti proses pembelajaran, menyusun kisi-kisi instrumen tes, menyusun soal tes.

\section{Pelaksanaan Tindakan}

Penelitian dilaksanakan dalam 2 jam pelajaran untuk setiap siklusnya. Masingmasing pertemuan disusun dalam satu rencana pembelajaran. Adapun langkah-langkah penelitian yang ditempuh pada setiap siklus dapat dijelaskan sebagai berikut:

\section{a. Perencanaan (planning)}

Dalam perencanaan ini meliputi pengenalan materi Klasifikasi Hewan, menyiapkan alat observasi dan praktikum klasifikasi hewan, pembentukan kelompok diskusi, dan menyiapkan angket aktifitas siswa dan kinerja guru.

\section{b. Pelaksanaan tindakan (acting)}

Dalam tahap pelaksanaan ini, dilaksanakan skenario pembelajaran yang telah direncanakan. Kegiatan pembelajaran ini secara umum meliputi:

\section{1) Pendahuluan}

Pada tahap ini dilakukan apersepsi dan motivasi kepada siswa.

\section{2) Kegiatan inti}

Siswa di bagi menjadi 6-7 kelompok, siswa melakukan observasi sesuai dengan petunjuk yang sudah dibagikan, siswa menyampaikan hasil observasinya,guru menyimpulkan atau mengevaluasi hasi observasi siswa.

\section{3) Penutup}

Pada tahap ini dilakukan penarikan kesimpulan dari kegiatan yang telah dilakukan.

\section{Pengamatan (observing)}

Pada kegiatan ini peneliti dibantu guru biologi dan sebagai guru mitra dan teman dalam melaksanakan observasi terhadap pelaksanaan tindakan untuk mengetahui pembelajaran menggunakan metode observasi. Guru mitra juga menjadi teman diskusi apabila ada hal-hal yang kurang jelas, juga untuk membantu mengatasi apabila ada permasalahan dalam proses kegiatan belajar mengajar (KBM).

\section{Refleksi (Reflecting)}

Hasil dari tahap observasi yang meliputi aktivitas siswa selama proses belajar mengajar (PBM), cara guru mengajar, hasil tes pada akhir siklus juga kendala-kendala yang dihadapi selama kegiatan pembelajaran dikumpulkan serta dianalisis sehingga diperoleh hasil refleksi kegiatan untuk mengetahui perubahan yang terjadi selama menerapkan pembelajaran menggunakan metode observasi. Hasil analisis data yang dilaksanakan dalam tahap ini digunakan sebagai acuan untuk melaksankan siklus berikutnya.

\section{Analisis Data}

Analisis data yang digunakan adalah analisis data deskriptif kualitatif dan kuantitatif. Teknik kualitatif digunakan untuk 
menggambarkan keterlaksanaan rencana tindakan, mengambarkan pelaksanaan pembelajaran dan mendeskripsikan aktivitas siswa dalam kegiatan pembelajaran. Sedangkan teknik kuantitatif digunakan untuk menganalisis pencapaian kemampuan kognitif siswa. Adapun Analisis data dilakukan sejak data diperoleh dari hasil observasi oleh peneliti. Data hasil penelitian dianalisis secara deskriptif untuk setiap siklus. Hal ini bermanfaat untuk rencana perbaikan pembelajaran pada siklus berikutnya.

HASIL DAN PEMBAHASAN
Penyajian data hasil penelitian diikuti dengan pembahasan. Hal ini dilakukan secara sistematis dengan mengikuti alur berpikir penelitian tindakan kelas (PTK), yang dijabarkan dalam dua siklus. Data yang dikumpulkan pada tahap perencanaan siklus pertama dan kedua meliputi data posttest yang dilakukan oleh siswa setelah pembelajaran siklus selesai, pada tahap pengamatan data yang diperoleh yaitu data aktivitas siswa dalam mengikuti pembelajaran. untuk sistimatisnya penyajian data disajikan pada tabel 1 berikut:

Berdasarkan Tabel 1. menunjukkan

\begin{tabular}{|c|l|c|}
\hline No & \multicolumn{1}{|c|}{ Kegiatan belajar mengajar } & $\begin{array}{c}\text { Presentase Ke- } \\
\text { tuntasan (\%) }\end{array}$ \\
\hline 1 & Sebelum Menggunakan metode pembelajaran observasi & 28,94 \\
\hline 2 & Sesudah menggunakan metode pembelajaran observasi siklus I & 44,74 \\
\hline 3 & Sesudah menggunakan metode pembelajaran observasi siklus II & 81,58 \\
\hline
\end{tabular}

Tabel 1. Data perbandingan Pemhaman siswa materi klasifikasi hewan pada setiap siklus pembelajaran

adanya peningkatan yang signifikan antara hasil pemahaman siswa sebelum menggunakan metode pembelajaran observasi dengan hasil pemahaman siswa setelah menggunakan metode pembelajaran observasi siklus I dan II.

Presentase jumlah siswa yang mendapatkan nilai tuntas sebelum menggunakan metode pembelajaran observasi adalah 28, 94\% pada siklus I mengalami peningka$\tan$ menjadi $44,74 \%$ tetapi belum mencapai kriteria ketuntasan minimal klasikal yang ditetapkan sekolah yaitu 75\% dan siklus II mengalami peningkatan kembali menjadi $81,58 \%$, sehingga presentase jumlah siswa yang mendapatkan nilai tuntas sudah mencapai indikator yang telah ditentukan sekolah dan hipotesis peneliti.

Peningkatan yang nampak pada presentase jumlah siswa yang mendapatkan nilai tuntas dari sebelum menggunakan metode pembelajaran siklus I dan II terjadi karena pada pembelajaran di siklus I siswa masih belum terbiasa belajar dengan meng- 
gunakan metode observasi. Hal tersebut sesuai dengan pernyataan yang diungkapkan oleh Dimyati dan Moedjiono (2009:254) bahwa siswa yang belum terbiasa dengan penggunaan metode atau model tertentu dan masih terbiasa dengan penggunaan metode atau model lama berpengaruh terhadap proses belajar siswa. Sehingga peningkatan pada siklus I belum teralalu signifikan sedangkan pada siklus II menunjukan peningkatan yang cukup signifikan yaitu $36,84 \%$. Hal ini ter- jadi karena siswa sudah mulai terbiasa dengan penggunaan metode observasi dan siswa lebih antusias dalam kegiatan pembelajaran karena termotivasi terhadap penghargaan yang diberikan oleh peneliti terhadap siswa yang aktif dalam kegiatan pembelajaran sehingga berdampak pada meningkatnya pemahaman siswa terhadap materi yang diajarkan.

Berikut perbandingan aktivitas belajar siswa siklus I dan siklus II:

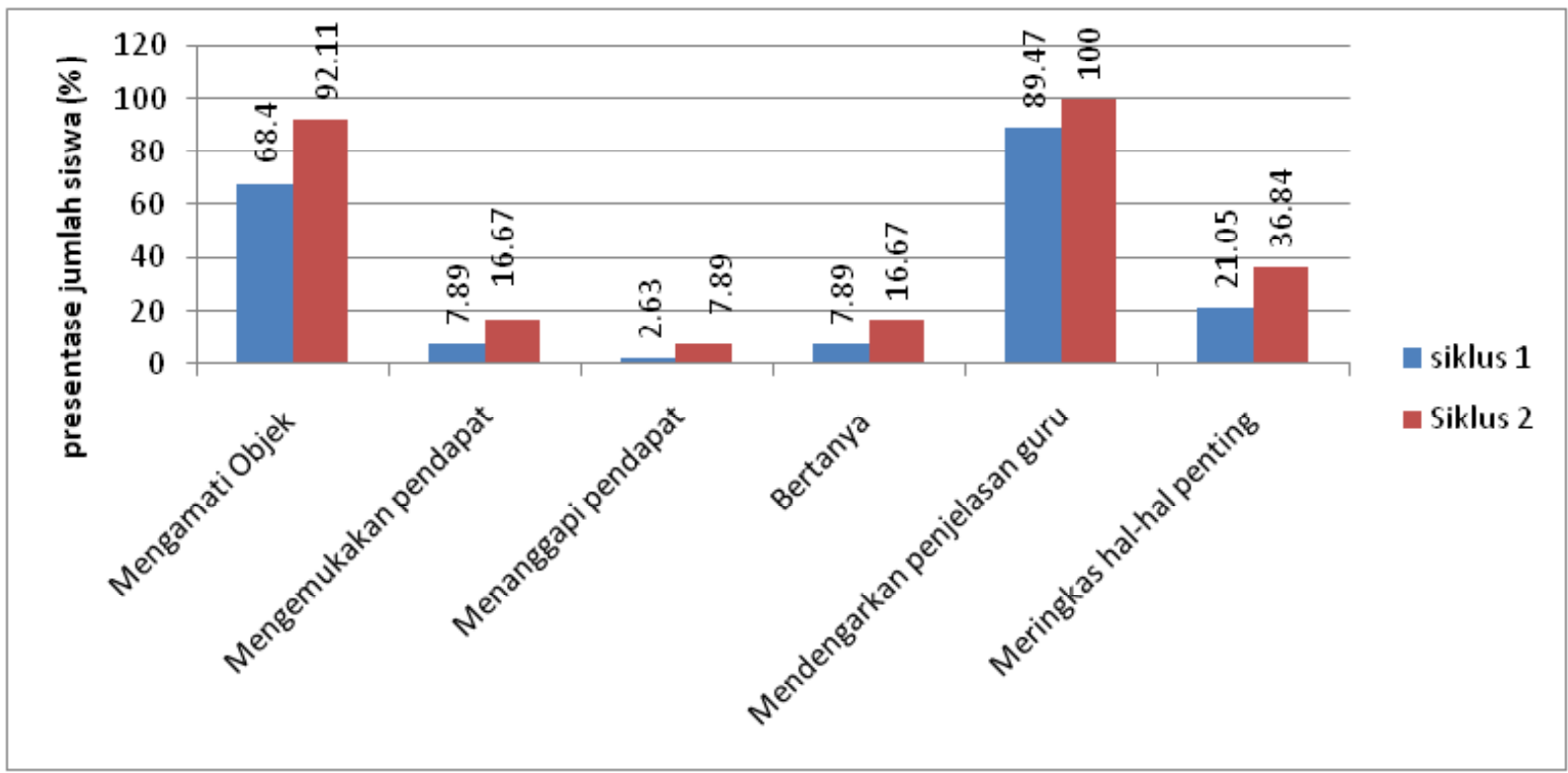

Berdasarkan gambar 1. menunjukan meningkatnya aktivitas siswa dari sikus I. Peningkatan aktivitas siswa tersebut terjadi karena proses pembelajaran pada siklus II lebih efektif. Selain itu peneliti memberikan penguatan kepada siswa untuk lebih aktif dengan memberikan penghargaan. Meningkatnya aktivitas siswa menunjukkan siswa sudah mampu berinteraksi aktif dan bekerjasama dengan teman sebayanya. Susana belajar yang menyenangkan dengan belajar di tempat yang diinginkan memberikan dampak yang positif dalam penerimaan siswa untuk memahami materi pembelajaran.

Menurut Susilo, M. J. (2009:80), suasana belajar turut menentukkan keberhasilan belajar siswa, suasana yang menyenangkan dapat menumbuhkan kegairahan siswa sedangkan suasana yang kacau, ramai, tak tenang dan banyak gangguan akan mengganggu konsentrasi belajar siswa. Oleh karena itu guru dan siswa senantiasa dituntut 
agar menciptakan susana lingkungan belajar yang baik dan menyenangkan menantang dan menggairahkan.

\section{KESIMPULAN DAN SARAN}

Kesimpulan

Berdasarkan hasil penelitian yang telah dilakukan dengan menggunakan metode pembelajaran observasi pada kelas VII B SMP Negeri 2 Kasihan Bantul Yogyakarta, dapat disimpulkan sebagai berikut:

Dapat diketahui bahwa penerapan metode pembelajaran observasi di kelas VII B sekolah SMP Negeri 2 Kasihan Bantul dapat terlaksana dengan baik sesuai dengan rencana kegiatan pembelajaran yang sudah dibuat dan dapat meningkatkan pemahaman siswa pada materi klasifikasi hewan.

Penggunaan metode pembelajaran observasi untuk meningkatkan pemahaman siswa kelas VII B pada materi pembelajaran klasifikasi hewan di SMP Negeri 2 Kasihan Bantul dapat dicapai melalui 2 siklus tindakan.

Terjadi peningkatan kemampuan pemahaman siswa dari siklus I ke siklus II melalui pembelajaran dengan menggunakan metode observasi yaitu ditunjukkan dengan nilai rata-rata kelas pada siklus I 66,18 sehingga dapat dikatakan belum memenuhi nilai standar ketuntasan minimal yaitu 70 . Sedangkan pada siklus II rata-rata nilai kognitif 75,39 mengalami peningkatan dari sik- lus I sebesar 9,21.

\section{Saran}

Berdasarkan hasil penelitian yang telah dicapai, maka dapat diberikan saran sebagai berikut :

\section{Bagi Guru Biologi :}

Guru perlu membuat skenario pembelajaran yang mendukung siswa untuk lebih aktif dalam kegiatan pembelajaran.

Hendaknya guru biologi menerapkan metode observasi pada materi-materi biologi yang lainnya sesuai dengan karakter metode observasi, karena metode observasi memudahkan siswa dalam memahami materi yang dipelajari.

Aktivitas siswa dalam mengemukakan pendapat dan menanggapi pendapat perlu dilatihkan agar siswa lebih terbiasa.

Bagi Sekolah: Kepala sekolah diharapkan lebih proaktif untuk mendorong setiap usaha guru untuk meningkatkan profesionalismenya melalui penelitian tindakan kelas guna mencapai proses dan hasil belajar yang maksimal.

Bagi Peneliti Lain, yang akan melakukan penelitian serupa, perencanaan/ persiapan matang sangat diperlukan, terutama dalam penyusunan dan validasi instrumen penelitian. Selain itu dalam melakukan validasi instrumen selain mengukur tingkat validitas instrumen peneliti juga perlu men- 
gukur tingkat reliabilitas instrumen penelitian.

\section{DAFTAR PUSTAKA}

Dimyati dan Mudjiono. 2009. Belajar dan Pembelajaran. Jakarta : Rineka Cipta.

Hamalik, Oemar, 2001. Proes Belajar Mengajar, Jakarta : Bumi Aksara.

Hasibuan dan Moedjiono. 2006. Proses Belajar Mengajar. Bandung : PT Remaja Rosdakarya.

Komaruddin dan Yooke Tjuparmah. 2007. Kamus Istilah Karya Tulis Ilmiah. Jakarta : Bumi Aksara.

Mardapi, Djemari. 2008. Teknik Penyusunan Instrumen Tes Dan Non Tes. Yogyakarta : Mitra Cendekia.

Susilo, Muhammad Joko. 2009. Sukses Dengan Gaya Belajar. Yogyakarta : Pinus 